\title{
Da Fiança e de alguns dos benefícios do fiador $(*)$
}

\author{
Moacir Amaral Santos \\ (Livre Docente de Direito Judiciário Civil
}

1. Remontam ao direito romano as origens de moderno instituto da fiança, espécie do gênero caução.

A cautio romana - de cavere, cautum, garantir reunia vários institutos juridicos que tinham por finalidade assegurar e garantir o cumprimento de uma obrigação (1). Repetindo WINDSCHEID, costumam os escritores dizer que as coutiones, tendendo a essa finalidade, operavam ou de modo

(*) Quando, no ano passado, concorremos à cátedra de Direito Judueiário Civill com o douto prof. Luiz Eulálio Bueno Vidrgal, gue com justiça a conquistou, apresentamos uma monograíia intitulada "Introducão ao estudo do Processo Cominatório". Dissemos, então, respondendo a um dos doutos componentes da comissão examinam. dora, ser mosso propósito prosseguir na obra, completando o estudo do processo cominatório, do qual aquela monografia era apenas a introdução. Estas páginas constituem um dos parágrafos dọ primeiro capitulo da obra prometida.

(1) Sôbre a cautio, ver Windscheid, Diritto alle Pandette, trad. de FADDA e Bensa, Torino, ed. 1930, 10., $\$ 134$; MaYins, Cours de drout romain, 1.0 vol., $\S 70 ; \mathrm{GLÜ}_{\mathrm{K}}$, Commento alle Pandette. trad. e motas de Sarafini e Cogliolo, liv. $2^{\circ} \S 243$ e ss.; Troplong, Le droit civil expliqué, ed. 1846, 170 vol. (Du cautionnement et des transactions), n. 2 e ss.; Peronaci (Ernesto), Della cuazione, Milano, ed. 1905; LEONI, Cautio e cauzione, em Digesto Italiano; CAGLI. Canzione, em Schaloja, Dizionario pratico del diritto privato; PaLERMO (Antonio), II procedimento cauzionale nel dirito romano. Milano, 1942. 
a estirpar de um direito qualquer dúvida, ou para asseguzar a boa vontade do devedor, ou para assegurar o direito contra obstáculos de fato (2).

Conhecida é a classificação que Ulpiano faz das calltiones, ou stipulationes praetoriae, em iudiciales, cautionales e communes (3). As indiciales eram as que se exigiam para que os juízos fossem válidos, tais a cautio iudicatum solvi, a cautio de rato, a cautio ex operis novi nuntiationes (4); as cautionales visavam reforçar o vínculo, criando ao lado da ação uma outra ação de maior eficácia, e tais eram a cautio de legatis stipulationis, a de tutela, a de ratum rem haberi e a de danni infecti (5); por communes se entendiam as cauções que garantiam a apresentação do réu em juízo (6).

As cautiones eram reais ou pessoais, aquelas, nos primeiros tempos, mais frequentes que estas: plus cautiones in re quam in persona, diz Pomponio (7).

(2) Windscheid, o. c., 10 vol., § 134; Peronaci, o. c., n. 1; Cagli, o. c., n. 2; Carvalho de Mendonça (M.I.), Contratos no direito civil brasileiro, 1938, Rio de Janeiro, $2^{\circ}$ vol., n. 374. "Os doutores e os comentadores antigos observam que a cautio era uma stipulatio ou verborum obligatio, mas, num sentido mais restrito, era uma promessa em face à siatisfatio, ou caução por meio de garantia. As cautiones serviam, também, para criar̆ uma relação jurídica ou assegurar a prova de uma relação, a fim de sußbtrair o direito de qualquer dúvida; e, enfim, em qualquer caso, tendiam elas a cavere, isto é, a garantir danos eventuais; donde ser de relevar-se a ampliação do significado atribuido ao remédio genérico das cautiones" (Peronaci, o. c., 2).

(3) D., 46, 5, 1.

(4) D., 46, 5, 1, 1. Cagli, o. e loc. cits. Adverte Peronacr, o. c., n. 4, que a essas três cautiones iudiciales dever-se-à acrescentar uma outra, de que tratam as Institutas, $3,18,1$, a cautio itticioIis de perseguendo servo.

(5) D., 46, 5, 1, 2. Peronaci, o. c., ns. 5 e segs.; Cagli, o. e loc. cits.

cits.

(6) D., 46, 5, 1, 3. Peronaci, o. c., n. 14; Cagli, o. e loc.

(7) D., 50, 25. 
a) Das cauções pessoais, a mais antiga era a sponsio, praticável sòmente entre cidadãos romanos; seguiu-se-lhe a fidepromissio, suscetivel de ser convencionada por peregrinos; e, finalmente, a fideiussio, extensível a uns e outros, e cuja existência já era conhecida por uma lei Cornélia, do ano 81 A. C. (8).

Pela fideiussio, alguém (o fiador), para garantia do credor, se obrigava para com êste ao lado do devedor (9). Ao fiador, perguntava-se: Idem fide tua esse iubes? E êle. respondia: Idem fide mea esse iubeo (10). Com estas palavras sacramentais firmava-se contrato solene entre a fiador e o credor, pelo qual era admissivel garantir-se tôda e qualquer espécie de obrigações (11).

Com a lex Furia os sponsores e os fidepromissores não. só se tornavam livres da obrigação após dois anos coma. também, na hipótese de serem vários os garantes, a dívida. dêstes se dividia entre êles. Não referindo-se a lei aos fideiussores, tais benefícios não os atingiam, donde as preferências ao instituto da fideiussio, que suplantou de vez a: sponsio e a fidepromissio, a ponto de Justrniano tratar nas Institutas apenas daquela (12).

b) No direito medieval vai se encontrar o instituto da fiança sob a denominação de pleiges, de cauxion, de praedes, da natureza dos fideiussores. Mas também, em seguida:

(8) Troplong, o. c., ns. 6-7; Dernaurg, Diritto delle obligaziomil, trad. de Francisco Bernardino Cicala, Torino, 1903, § 76, n. $1_{2}$ Gaio, Inst., 3, 115: — ${ }^{\star P}$ Pro eo quoque, qui promittit, solent alli obligori: quorum alios sponsores, alios fidepromissores, alios fideius-sores appellamus".

(9) Inst., 3, 20; D. 46, 1; DernburG, o. c., § 76, n. 1.

(10) D. 1, 46, 16, 6. GAIO, 3, 116: - "Sponsor ita interrogatur: IDEM DARI SPONDES? fidepromissor: Idem Fidepromittis? fideiussor: Idem fide tua esse jubes? videbimus de his autem, quo nomine possint proprie appelari, qui ita interrogantur: Idem dabis? Idem promittis? Idem facies?"

(11) Troplong, o. c., n. 7; Dernburg, o. e loc. cits.

(12) Derniburg, o. e loc. cits.; Troplong, o. c., n. 8. 
A êsses, surgiram garantias ou cauções de indolle moral, ou juramentos, v. g., o iuramentum calumnioxe (13).

2. A fiança, no direito moderno, como no romano, é um contrato pelo qual alguém se obriga por um devedor a favor de um credor, a fim de the pagar em todo ou em parte o que o devedor lhe deve, accedendo is sua obriyação. Tal é a definição de Pothier, cuja doutrina foi rgasalhada pelo código civil francès (14) e repetida pelos códigos contemporâneos (15).

Com o mesmo espírito dêstes, o Código Civill brasileiro, art. 1.481, define: - "Dá-se o contrato de fiança, quando uma pessoa se obriga por outra, para com o seu credor, a satisfazer a obrigação, caso o devedor não a cumpra".

Assim, a fiança fornece ao credor uma garantia: é, pois, um contrato de garantia, e que consiste ma obrigaçã́o qu o fiador assume, perante o credor, de satisfazer a - brigação do devedor, caso êste não a satisfaça. À obriga๔̧ão do devedor, se acrescenta a do fiador, sem que haja aumento da divida, que perdura tal qual aquêle contráu; donde o credor ficar com o seu crédito mais garantido,

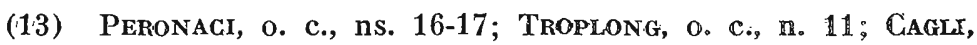
o. c., n. 3; Salvioli, Manuale di storia del diritto italiono, ed. 1925, págs. 442 e segs.

(14) Pothier, Tratado dasi obrigaçóes pessoais e reciprocas, tríad. de Corrêa Teles, $10^{\circ}$ vol., n. 366; Código Civill rrancês, art. 2. 011; Laurent, Principii di diritto civile, 1a ed. da trad. italiana, Milão, 1901, 280 vol., n. 117; BAUdry-LAcantinerie et WAHE, Traité théorique et pratique de droit civil, Paris, 2" ed., 1900, 210 vol., in. 909; Planiol, Traité élémentaire de droit civil. 4.a ed., 1907, Paxis, 20 v. n. 2323.

(15) Cód. Civil Alemão, § 765; italiano, de 1865, art. 1898; italiano, art. 1936; português, art. 818; espanhol, art. 1822; argentino, art. 1986; uruguaío, artigo 2076. 
pois ao invés de um devedor, o que contraiu a obrigação, dois se tornam os obrigados pela mesma dívida (16).

Trata-se de garantia pessoal: responde pela dívida o patrimônio do fiador. $E$ nisso se distingue a fiança dos contratos de garantias reais, pelos quais o próprio devedor. ou terceiro, para segurança do credor, lhe oferece um bem em garantia da dívida, como no penhor ou na hipoteca.

a) Mas a relacão entre o devedor e o credor difere da que se estabelece entre êste e o fiador.

o contrato entre aquêles cria a dívida, faz nascer a obrigação principal, no sentido de que existe ou pode existir por si só. O fiador nada mais faz do que, para garantia do credor, obrigar-se para com êste pela prestação do devedor; donde, o contrato que se forma entre o fiador e o credor supor uma obrigação preexistente, à qual se prende pelo vínculo que une o acessório ao principal (17). De conseguinte, a obrigação do fiador è acessória, subsidiária, eventual, isto é, dependente da preexistência da obrigação principal, do devedor.

b) A vontade de prestar fiança deve ser expressa (18), isto é, a fiança deve resultar de uma manifestação expressa da vontade de quem a presta (19). Mas não basta a vontade do fiador, sendo necessária também a do credor, vale

(16) "Seria preciso que um e outro (devedor e fiador) se tornassem insolváveis, para que o credor perdesse o montante do seu crédito". (Baudry-Lacantinerie et Wahl, o. c., 210 vol. n. 909).

(17) Baudry-Lacantinerie et Wahl, o. c., $21^{\circ}$ vol., n. 914; PlaNIOL, o. c., $2^{\circ}$ vol., n. 2.324; Pothier, o. c., 10 vol., n. 366; LAURENT, o. c., $28^{\circ}$ vol. n. 117; Troplong, o. c., n. 22; Mirabeli, Contratti speciali, ed. 1904, Napoli, pág. 392; Redentr, Fideiussione, n. 6, em Scraloja, Dizionario pratico del diritto privato; Clóvis Bevilaqua, Código Civil Comentado, 1926, 5o vol., pág. 246; Carvalho de MeNDONÇa (M.I.), o. c., $2^{\circ}$ vol., n. 377; GaMa (Afonso Dionisio da), o. c., § 2.0; Machado Guimarães, Comentários ao Código de Processo Civil, 1942, $4^{\circ}$ vol., n. 170.

(18) Cód. civil italiano, art. 1937.

(19) BeLmonte (Guido) e outros, II nuovo codice civile comentato, liv. $4^{\circ}, 2^{\circ}$ tômo, pág. 418. 
dizer, que se estabeleça o encontro de vontades de ambos, o in idem placitum, que dá existência ao contrato (20). Por outras palavras, a fiança depende do consentimento das partes, fiador e credor. A simples promessa ao devedor de assumir a sua dívida não constitui fiança, observa Carvalho DE Mendonça, reproduzindo Dernburg (21).

E por isso se tem que a fiança é um contrato consensual (22).

c) Geralmente, tão só o fiador se obriga para com o. credor, sem que êste, em troca, se obrigue em relação àquele. Essa particularidade da fiança leva os juristas francêses a qualificá-la de contrato unilateral (23).

Todavia, - adverte Carvalio de Mendonça - no comum dos casos a fiança é consertada entre o fiador e o devedor. $\mathrm{E}$, assim, vista a fiança apenas em relação ao credor, será ela um contrato unilateral. Mas se o fiador pagar a divida, ocorre que êle se subroga nos direitos do credor (24), donde poder voltar-se contra o devedor para obter dêste o cumprimento da obrigação. Assim encarada, considera-se a fiança contrato bilateral imperfeito (25).

d) A fiança deve ser expressa (26).

(20) Carvalho de Mendonģa (M.I.), o. c., $2^{\circ}$ vol, n. 379; GaMA (Afonso Dionisio da), o. e loc. cits.

(21) Carvaliho de Mendonça (M.I.), o. e loc. cits.

(22) Carvalyo de Mendonça (M.I.), o. e loc. cits.; Gama. (Afonso Dionisio da), o. e loc. cits.; Clóvis Bevilaqua, o. c., 5.0 vol., pág. 246; Planioz, o. c., 20 vol., n. 2.324; Lomonaco, Istituzioni dr̈ diritto civile italiano, $2^{a}$ ed., $1895,6^{\circ}$ vol., pág. 571.

(23) Planiol, o. c., $2^{\circ}$ vol., n. 2.324; Baudry-Lacantinerie et Wahl; o. c. $21^{\circ}$ v. n. 913 ; Laurent, o. c., $28 .^{\circ}$ vol., n. 126 ; Troplong, o. c., n. 18 .

(24) Código Civil, art. 1.495.

(25) Carvalho de Mendon'ça, o. c., $2^{\circ}$ vol., n. 379; Gama (Afonso Dionisio da), o. e loc. cits.; BevilaQua, o. c., $5^{\circ}$ vol., pág. 246.

(26) Planiol, o. c., $2^{\circ}$ vol., n. 2.324; Troplong., o. c., n. 133 e ss.; Laurent, o. c., $28^{\circ}$ vol., n. 153; Baudry-Lacantinerie et WaHL, o. c., $21^{\circ}$ vol., n. 929; Mrabelli, o. c., pág. 406; Carvalho de Men- 
Expressa, no sentido de que a fiarça não se presume.. O caráter do contrato, pelo qual obrigações de outrem são" garantidas pelo fiador, pressupõe manifestação positiva e certa da vontade dêste (27), donde afastar-se a hipótese deser presumida. Aliás, no direito pátrio, alémm de expressa, a fiança, tendo em vista esta ponderação, deve também: ser dada por escrito (Cód. Civil, art. 1.483).

Consequência é que, relativamente à fiança, não seadmite interpretaçâo extensiva (Cód. Civil, art. 1.483). Quer dizer, em sintese, que a fiança é de direito estritíssimo: fideiussio est strictissimi iuris (28).

c) Finalmente, ế um contrato gratuito, ou benéfico, em. relação ao devedor (29), porque êste goza os favores da fiança a título gratuito, isto é, sem que o fiador disso aufiram qualquer vantagem. $O$ caráter de beneficência não existeem relação ao credor, porque - já o dizia Pothier - êsté "não recebe pela fiança mais do que lhe é devido, sem a qual êle não teria contratado com o devedor principal". Todavia, o caráter de beneficência predomina, porque, normalmente, a causa do contrato é o simples interêsse do

DONGA (M.I.), o. c., $2^{\circ}$ vol., n. 38.2; Bevilaqua, o. c., 5o vol., pág. 248;: Carvalho Santos, Código Civil Brasileiro Interpretado, 1938, $19^{\circ}$ vol., pág. 457 e ss.; Gama (Afonso Dionísio da), o. e loc. cits.

(27) Bevilaqua, o. c., $5^{0}$ vol., pág. 247.

(28) Pothier, o. c., $1^{0}$ vol., n. 405; Troplong, o. c., n. 134 e ss.; Mrrabelli, o. e loc. cits.; Bevilaqua, o. e loc. cits.; Carvalho SANTos, o. e loc. cits. "A fiança deve ser expressa e não presumida, nem admite interpretação extensiva de re ad rem, de persona ad personam, de tempore ad tempus, pois que o fiador se obriga por divida que lhe não interêssa" CaRvalmo de MEndonģ.A (M. I), o. c., 2 o vol., n. 382 , pág. 475).

(29) Pothier, o. c., $1^{0}$ vol., n. 366 ; Troplong, o. c., n. 13; Laurent, o. c., $28^{\circ}$ vol., n. 122 e ss.; Baudry-Lacantinerie et Wahl, o. c., 210 vol., n. 915; Planiol, o. c., $2^{\circ}$ vol., n. 2324; Bevilaqua, o. c., $2^{\circ}$ vol., p. 246; Carvalho de Mendonģa (M.I.), o. c., 20 vol., n. 379; Gama (Afonso Dionísio da), o. e loc. cits. 
fiador em ajudar gratuitamente o devedor, ao qual se liga por laços afetivos ou semelhantes (30).

Por vêzes, e hoje em dia não mui raras, deixará a fiança de apresentar carater de gratuidade, ou de beneficicência (31), o que ocorre em diversas hipóteses: quando o fiador, em troca da obrigação que assume, exige do devedor o pagamento do serviço que lhe presta; quando o fiador estipula, em seu benefício, uma certa compensação do credor; quando o fiador estipula lhe pague o devedor o preço dos riscos que corre; quando o fiador estipula, em troca da garantia que presta, que o credor conceda ao devedor principal uma determinada vantagem, como, por exemplo, uma prorrogação de prazo, uma redução de juros. Em tais casos, porém, não se verificam típicos contratos de fiança. Basta considerar que às três primeiras hipóteses, sem embargo das distinções dos doutores apresentando-lhes soluções diferentes, bem se lhes aplica o ensinamento de CarvalHo DE Mendonça de que a convenção de fiança "entra na comissão del credere e então é um verdadeiro seguro, em que - fiador toma a si o risco da falta do devedor. É neste caso um contrato aleatório e principal e não uma verdadeira fiança" (32). Aliás, contratos dessa natureza fogem ao

(30) "Normalmente, com efeito, é a título gratuito entre o fiador e o devedor; é um ato de amizade, de afeição, bonitatis et humanitatis, como disse QUINTILIANO. O fiador oferece sua fortuna e seu crédito para prestar um serviço ao devedor. A lei não lhe assegura nenhuma vantagem compensatória" (TroploniG, o. c., n. 13).

(31) O Código Comercial brasileiro, art. 259, permite que o fiador mercantil estipule do afiançado uma retribuição pecuniária pela responsabilidade da fiança. No mesmo sentido o direito francês, o italiano, o cód. comercial espanhol, art. 441, o cód. comercial argentino, art. 483. Troplong, o. c., n. 15 e ss.; Laurent, o. c., 280 vol., n. 124 e ss.; BAUdry-LACANTinerie et WAHL, o. c., 210 vol., ns. 1006 e 1.071; Plantol, o. c., $2^{\circ}$ vol., n. 2.324; Redenti, o. c., n. 3; Mirabeli, o. c., pág. 395; Carvalho de Mendonç.a (M.I.), o. c. $2^{\circ}$ vol., n. 379 .

(32) Carvalho de Méndonça (M.I.), o. c., $2^{\circ}$ vol., n. 379. 
contrato de fiança normal e típico, cumprindo ser apreciados cada um de per si. "Um estudo geral - observa REDENTI - não pode dedicar a essas hipóteses senão algumas referências, sob pena de perder-se no mare magnum da causística" (33).

3. Como espécie de gênero cauçâo, a fiança se divide em legal, judicial e convencional. Bem se vê que é desta que se vem tratando e tão sòmente dela falar-se-à, porque as demais não interessam a êstes estudos.

A convencional, por sua vez, ou é civil (34) ou é comercial (35) É civil quando visa assegurar o cumprimento de qualquer obrigação civil; é comercial quando "o afiançado seja comerciante e a obrigação afiançada derive de causa comercial, embora o fiador não seja comerciante" (Cód. Comercial, art. 256).

4. Visto que o fiador, pelo contrato de fiança, garante ao credor a obrigação do devedor, resulta que dêsse contrato surtem duas ordens de efeitos: efeitos do fiador em relação ao credor e efeitos do fiados em relação ao devedor.

Nesses efeitos consubstanciam-se direitos do fiador, alguns dos quais precisam ser examinados em consideração aos fins objetivados pelo capítulo.

5. Atendo-se rigorosamente à finalidade da fiança garantia que o fiador presta ao credor pelo cumprimento da obrigação do devedor, - vale dizer, atendo-se a que ao fiador se impõe o cumprimento da obrigação "caso o devedor não a cumpra" (Cód. Civil, art. 1.481), será de concluir-se que, não satisfeita pelo devedor a obrigação no prazo fixado, surge para o fiador o imperativo de dar-lhe cabàl cumprimento. O vencimento da obrigação do devedor

(33) Redenti, o. c., n. 3.

(34) Cód. Civil, arts. 1.481-1.504.

(35) Cód. Comercial, arts. 256-264. 
importa o vencimento da obrigação do fiador, e contra qualquer dos obrigados poderá dirigir-se o credor par exigir que a satisfaça. Nem outra razão explica ter o credor pror curado dois obrigados para a mesma obrigação.

Realmente, desde que o devedor não cumpra a obrigação, toca ao fiador cumprí-la. Ao credor cabe escolher de quem exigí-la, se do devedor, se do fiador, se de ambos (36). Ocorre aqui a figura do concurso de ações, ou seja, a faculdade do credor, tendo várias ações para a defesa do mesmo direito, escolher uma delas (37).

a) Entretanto, não obstante isso, porque em relação ao devedor a fiança normalmente é um contrato de beneficência, desde as mais remotas eras preocuparam-se juristas e legisladores com amparar o fiador contra investidas severas do credor. A lex Furia abrandara os rigorés da sponsio e da fidepromissio (38). Leis viriam suavisando a fideiussio.

Certo è que no mais antigo direito romano ao credor era facultado agir indistintamente contra o fiador ou o devedor principal (39). Vigorava a libera electio, isto é, cabia ao credor escolher de quem convinha exigir o cumprimento da obrigação. 'Tal ainda era o direito ao tempo dos Antoninos (40). O imperador Alexandre Severo escrevia, no ano 209, ao seu procurador: "Se teu relato merece fé, nossos procuradores fizeram mal em não ouvir-te quando pedias que o pagamento se fizesse sôbre os bens do fiador, ordenando-te que citasses o devedor principal, uma vez que o credor tem livre escolha" (41). Idêntica a decisão de Antonio Caracala, no ano 215: "Segundo nosso direito, pode o cre-

(36) Carvalho Santos, o. c., 190 vol., pág. 462; Cunha GonGalves, Tratado de Direito civil, $1^{a}$ ed., 5. vol., p. 181.

(37) Rezende Filho (Gabriel de), Curso de direito processual civil, $2^{a}$ ed., 1952, $1^{\circ}$ vol., n. 193 e ss.

(38) Vide n. 1, " $a$ ".

(39) Derniurg, o. c., $\S 78$, n. 3; Windscheid, o. c., § 478, nota 1 .

(40) Troplong, o. e loc. cits.; Pothier, o. e loc. cits.

(41) C., $8,41,3$. 
dor exigir o pagamento aos fiadores preferentemente ao devedor, salvo se outra coisa houvesse sido especialmente convencionado" (42). Ainda a mesma era a jurisprudência ao tempo de Deocleciano (43), dezenas de anos depois.

No direito clássico, para que o fiador pudesse forçar que primeiramente fôsse acionado o devedor principal, inventou-se a chamada fideiussio indemnitatis, consistente na cláusula pela qual aquêle se obrigava tão sòmente pelo saldo da dívida (44). Expressivos, a respeito, são textos de Papiniano, Juliano e Scaevola (45).

Considerando que o fiador "se obriga subsidiàriamente" e que, portanto, é o devedor principal quem "deve em primeiro lugar cumprir o contrato", Justiniano transformou, na espécie, o direito até então vigente, expedindo uma constituição pela qual se exigia que os credores demandassem primeiramente o devedor principal: ut creditoris primo loco conveniant principalem (46).

Na verdade, ao promulgar tal constituição, Justiniano dizia assim proceder por entender "indispensável repiôr em sua fôrça e vigôr uma antiga lei caída em desuso por motivos ignorados" (47). Todavia, Troplong não poude atinar com segurança qual fôsse essa antiga lei, sem embargo reconhecesse dela existirem vestígios (48). O que não hả dúvida, porém, é que, a partir de Justiniano o credor não devia dirigir-se contra o fiador "sem que primeiro se dirigisse contra o que recebeu o dinheiro e contraiu a dívida" - "sed veniat primum ad eum qui aurum accepit, debitum

(42) $\mathrm{C}_{\text {r, }}$ 8, 41, 5: "Iure nostro, est potestas creditori, relicto reo, eligendo fideiussores, nisi inter contrahentes aliud placitum doceatur".

(43) C. 8, 41, 19; C., 8, 41, 21.

(44) Troplong, o. e loc. cits.; Baudry-Lacantinerie et WAHL, o. c., $21^{\circ}$ vol., n. 1.021 .

(45) D., 45, 1, 116; D.; 46, 1, 16, 6; D., 46, 1, 63.

(46) Novela 4, cap. I.

(47) Novela 4, pref.

(48) Troplong, o. c., n. 225. 
contraxit" (49). E assim se instituíu $u$ direito do fiador exigir do credor que, antes de impor-lhe o cumprimento da obrigação, agisse contra o devedor principal (50). Esse o direito do fiador conhecido por beneficium excussionis, benefício de excussão, ou de discussão, beneficio de ordem, ou, ainda, exceção de ordem.

b) Direito inspirado na equidade, no interêsse de não sacrificar-se o fiador sem maiores vantagens para o credor, que bem poderá inúmeras vêzes obter do próprio devedor principal a satisfação do seu crédíto, o beneficium excussionis com o decorrer do tempo penetrou no direito de quase todos os povos.

A sua adoção no direito francês foi lenta e demorada (51). Igualmente não o conheceram os costumes gerniâ= nicos e a idade média (52). A Rota de Gênova dêle dizia: excussio habet in se summam aequitatem (53); entretanto, repelia-o o direito canônico (54). Mas, com os estudos do direito romano, em França, o beneficio de ordem, já admitido pelo direito costumeiro, ali se introduziu (55); daf passou para o cỏdigo civil e se estendeu ao direito da generalidade dos povos (56).

No velho direito português, já as Ordenações Manuelinas regulavam êsse benefício do fiador ( 57$)$, delas passando para as Ordenações Filipinas, que rezavam: (58)

(49) Novela 4, cap. I.

(50) Pothier, o. c., $11^{\circ}$ vol., n. 408; Troplong, o. c., n. 225; Dernburg, o. c., $\S 78$, n. 3; Baudry-Lacantrnerie et Wahl, o. c., 210 vol., n. 1.021; Carvalho de Mendonga (M.I.), o. c., $2^{\circ}$ vol., n. 385.

(51) Troplong, o. c., n. 229.

(52) Carvalho de Mendonga, o. c., $2^{\circ}$ vol,, n. 385.

(53) A pud Lomon'Aco, o. c., 60 vol., p. 583.

(54) Tropiong, o. c., n. 229.

(55) Baudry-Lacantinerie et WaHL, o. c., $21^{\circ}$ vol., n. 1.021.

(56) Cód. civil francês, art. 2.021; italiano, de 1865, art. 1907; português, art. 830 ; argentino, art. 2012 ; alemão, $\S 771$.

(57) Ord. Manuelinas, liv. 4, tit. 46, § $1^{\circ}$.

(58) Ord. Filipinas, liv. 4, tit. 59, pr. No mesmo sentido as mesmas Ord., liv. 4, tit. $61, \S 8^{\circ}$ : "E nos casos, onde as mulheres 
"O fiador não deve ser demandado em algum caso, até que o principal devedor seja primeiro demandado, e condenado, e feita a dita execução, no que se nâo poder haver pelos bens do principal, poderá ser demandado o fiador".

Este o direito brasileiro, aliás consolidado por Teixeira de Freitas e depois por Carlos de Carvalho, (59) que se integrou no Código Civil, cujo art. 1.491 dispõe: "O fiador demandado pelo pagamento da divida tem o direito de exigir, até a contestação da lide, que sejam, primeiro, excutidos os bens do devedor".

6. Não cumprindo o devedor principal a obrigação e tendo o fiador que satisfazê-la, seria ếste inìquamente prejudicado se lhe não assistisse o direito de regresso contra aquêle, a fim de ver-se reembolsado. Nisso consiste o principal efeito da fiança entre o devedor e o fiador.

a) Em direito romano, há que distinguir-se a ação concedida ao sponsor da conferida an fidepromissor e ao fideiussor.

Ao sponsor atribuira a lex Publilia a actio depensi, pela qual podia pedir ao devedor principal o reembolso da quantia por êle paga ao credor. Caracterizava-se tal ação por favorecer o sponsor com o direito de exigir o pagamento em dôbro - actionem in duplum - no caso do devedor contestar infundadamente divida (6).

não podem gozar do benefício do Veleano, segundo acima temos declarado, poderão gozar do benefício, por Direito outorgado aos fiadores, que por outrem se obrigam, para que não possam por essa obrigação ser demandados, nem feita execução em seus bens, até que primeiro sejam demandados, e condenados e executados os principais devedores". Sốbre o processo de execução nos bens do fiador, Ord., liv. $3^{\circ}$, tit. 92.

(59) Teixeira de Freitas, Consolidação das leis civis, art. 788; Carlos de Carvalho, Direito civil brasileiro recopilado, ed. 1915, Porto, art. 1.372.

(60) Gaio, 3, 127: "In eo quoque par omnium causa est, quod, si quis pro eo solverit, ejus recuperandi causa habet cum eo man- 
Diversamente, sos fidepromissores e os fideiussores, para reclamarem $\_$. reembolso, tinham a actio mandati: " $O$ fiador, que pagou qualquer coisa pelo devedor principal, pode agir contra êle por meio da ação de mandato, a fim "de se reembolsar" (61). Entendia-se que a fiança se dera a pedido do devedor ou na consonância da sua vontade, e, portanto, por ordem ou mandato dêste. Assim, ao fiador, - como mandatário, competia a actio mandati para rehaver do mandante o que por êle pagara.

Mas, para considerar o fiador mandatário do devedor, urgia que a fiança houvesse sido prestada com consentimento ou, ao menos, com conhecimento dêste, sem o que nẫo se podia falar em mandato expresso ou tácito. De tal forma, prestada. que fôsse a fiança com desconhecimento do devedor, os jurisconsultos romanos, para não deixarem :o fiador ao desabrigo quando saldasse a dívida dêste, vikram no seu ato uma gestão de negócio e lhe conferiram a actio negotiorum gestorum (62).

dati iudicium; et hoc amplius sponsores ex lege Publilia propriam Ihabent iactionem in duplum, quae appellatur depensi". Do carater in duplum da actio depensi, ver, ainda, GaIo, 4, 9: "Rem vero et poenam persequimur, velut ex his. causis, ex quibus adversus infitiantem in duplum agimus: quod accidit per actionem iudicati, depensi, damni in iuriae legis Aquiliae aut legatorum nomine quae per damnationem certa relicta sunt". E PAULo, Sententiarum receptarum, 1, 19, 1: "Quaedam actiones, si a reo infitientur, duplantur, velut iudicati, depensi, legati per damnationem relicti, damni iniuria legis Aquiliae; item de modo agri, quum a venditore emptor aleceptus est". "Cf. Troplong, o. c., n. 326; Derinburg, o. c., $\S 80$.

(61) Justiniano, Inst., 3, 20, 6: "Si quid autem fideiussor pro reo solverit, èius recuperandi causa habet cum eo mandati iudicium". No mesmo sentido GAro, 3, 127, transcrito na nota anterior; Ulpianio, D., 17, "1, 6, 9. G. Troplong, o. c., 327; Dernburg, o. c., $\S 80$; Windscheid, o. c., $2^{\circ}$ vol., $\S 481$; Pormier, o. c., $1^{\circ}$ vol., $\$ 430$.

(62) PAUlo," "'D., "17, 1, 20, 1: “Fideiussori negotiorum gestorum est actio, si pro absente fideiusaerit: nam mandati actio non potest competere, cum non antecesserit mandatum". PAuno, D., 17, 1, 40: Si pro te praesente et vetante fideiusserim, nec mandati ac- 
Acontecia, porém, que, sendo de natureza pessoal a actio mandati e a actio negotiorum gestorum, o fiador comumente, conquanto viesse pagar dividas também asseguradas com garantias reais do próprio devedor, uma vez que o pagamento extingue a obrigação, ao regressar contra êle por uma daquelas ações não mais encontrava bens sôbre os quais recaísse o seu crédito. Essa situação levou os jurisconsultos romanos a conceber o pagamento do fiador com a correspondente cessão de ações, isto é, o fiador, ao pagar, exigia que o credor The cedesse o crédito com todos os seus acessórios e vantagens: "dêsse modo - escreve Troplong - êle ficava investido do direito de fazer valer, como se fôsse o próprio credor, as hipotecas sôbre os bens do devedor e as ações contra os coobrigados" (63). Graças a êsse engenho dos prudentes, o fiador podia compelir o credor a fazer-lhe a cessão sob pena de não efetuar-lhe o pagamento: nisso consistia o beneficium cedendarum actionum (64).

Discute-se, em direito romano, se êsse benefício era assegurado ao fiador ipso iure, isto é, pelo só fato de haver pago o credor (65), ou se para gozà-lo devia o fiador so-

tio nec negotiorum gestorum est: sed quidam utilem putant dari oportere: quibus non consentio, secundum quod et POMPONIO videtur". C.f. Troplong, o. c., $2^{\circ}$ vol., \& 481; Pothier, o. c., 10 vol., $\S 430$; Carvalho de Mendonç, o. c., 20 vol., n. 387.

(63) Troplong, o. c., ns. 356-357.

(64) Troplong, o. c., n. 357 e ss.; Dernburg, o. c., § 80, n. 2; Windscheid, o. c., $2.0^{\circ}$ vol., $\S 481$; Carvalho de Mendonģa (M. I.), o. c., 2. ${ }^{\circ}$ vol., n. 385. Paulo, D., 46, 1, 36: "Cum is qui et reum et fideiussores habens ab uno ex fideiussoribus accepta pecunid praesttat actiones, poterit quidem dici nullas iam esse, cum suum perceperit et perceptione omnes liberati sunt, sed non ita est: non enim in solutum accipit, sed quadammodo nomen debitoris vendit, et ideo habet actiones, quia tenetur ad id ipsum, ut praestet actiones".

(65) Nesse sentido, Dernburg, o. c., $\S 80$, nota 7 , fundado no texto de Paulo, transcrito na nota anterior. 
licitar e obter a cessão como condição para o pagamento. (66).

b) No direito francês anterior ao Código Civil, ao lado da actio mandati contraria e da actio negotiorium gestorum existia o beneficium cedendarum actionum. Para que êste tivesse lugar, era preciso que o fiador, ao pagar, se fizesse subrogado nos direitos e ações do credor; na falta de subrogação expressa, o fiador teria aquelas ações, conforme a fiança houvesse sido prestada com ciência e aprovação do devedor ou sem conhecimento dêle (67).

Tais distinções desapareceram, pràticamente, no direito moderno, que torna o fiador, que paga o credor, subrogado, ipso iure, nos direitos e ações dêste contra o devedor. "O fiador, que paga a dívida - dispõe o Código Civil francês (68) - é subrogado em todos os direitos que tinha o credor contra o devedor".

c) As Ordenações Filipinas (69) prescreviam o beneficium cedendarum actionum: "E pagando o fiador a condenação em parte, ou em todo, traspassarão em êle todos os direitos e ações, que o vencedor da dita condenação houvesse, e lhe por direito pertencesse contra o condenado, para haver recurso contra êle, e seus bens, que na terra. forem achados, e cumpridamente haver, e cobrar o que por êle tiver pago, com tôdas as custas e interêses e perdas, que por causa da fiança tiver recebidas". A inteligência dêsse texto admitia divergências - observa CoELHo DA RocHA (70) - havendo quem, como Melo Freire (71), enten-

(66) Assim pensa Troplong, o. c., ns. 357-360. Tal era o ensinamento de Modestino, D., 46, 3, 76.

(67) Pothier, o. c., 1.0 vol., n. 430; Troplong, o. c., n. 356 e ss.

(68) Cod. Civil francês, art. 2.029. No mesmo sentido: Cód. Civil alemão, \& 774; italiano, de 1865, arts. 1.915-1.916; italiano, art. 1.949; federal suisso das Obrigações, art. 505; português, arts. $838,839$.

(69) Ord., liv. 3.०, tit. 92.

(70) CoElho DA Rocha, Instituições de direito civil português, $4 .^{a}$ ed., 1.857, Coimbra, 2.0 vol., n. 884 . 
desse perdurar aí a distinção romana, tal qual no antigo direito francês.

Entretanto, no direito pátrio anterior, afastada se achava qualquer dúvida e proclamado o princípio de que o fiador, que pagava a dívida, se subrogava nos direitos do credor contra o devedor, independentemente de cessão expressa. Era o princípio reconhecido por CARLOS DE CARvalHo (72) e, anteriormente a êle, pelo Código Comercial, cujo art. 260 reza: "O fiador que paga pelo devedor fica subrogado em todos os direitos e ações do credor".

Idêntica a norma do art. 1.495, do Cód. Civil: "O fiador, que pagar, integralmente, a divida, fica subrogado nos direitos do credor". Quer dizer que passam ao fiador todos os direitos do credor contra o devedor, com tôdas as garantias que lhe eram asseguradas, independentemente de cessão expressa (73). Tal é o chamado benefício de subrogação: o fiador é subrogado em todos os direitos do credor.

7. Em regra, o fiador terả regresso contra o devedor desde que pague o credor (74). De tal modo cobre-se êle de que pagou a êste, por uma dívida que não era sua.

Mas não seria razoável nem conforme os princípios da equidade fôsse forçado o fiador, em todo e qualquer caso, a pagar para em seguida agir regressivamente contra o devedor quando evidente que, a assím proceder, o seu sacrifício se tornaria fatal. Tais as circunstâncias, aconselha a

(71) Melo Freire, Institutiones Juris Civilis Lusitani, ed. 1853, Coimbra, liv. $4 .^{\circ}$, tit. $3, \S 28$.

(72) Carlos de Carvalho, o. c., art. 1.377; Teixeira de Freitas, Cons., art. 796 e nota. Igualmente a doutrina então dominante: Coelho da Rocha, o. e loc. cits.; Corrêa Teles, Digesto Português, 4. ${ }^{\mathrm{a}}$ ed., 1853, Coimbra, 1.o vol., 435.

(73) Clóvis Bevrlaqua, o. c., 5.0 vol., pág. 261; Carvalho Santos, o. c., $19 .^{\circ}$ vol., pág. 471 e ss.; Carvalho de Mendonga (M. I.), o. c., $2 .^{\circ}$ vol., n. 386; Laurent, o. c., $28 .^{\circ}$ vol., n. 344; Troplong, o. c., ns. 362, 371 e ss.; Planiol, o. c., 2.0 vol., n. 2.357.

(74) Vide n. 6. 
razão, e é conforme o direito, que o fiador, ainda antes de pagar a dívida, possa agir de forma a evitar seu prejuizo certo. Aplicação de regra que Justiniano eternizou: é melhor conservar intactos os direitos que procurar-lhes remédio quando sacrificados (75).

a) Com êsse fundamento, o direito romano concedia ao fiador, mesmo antes que houvesse pago a dívida, o direito de ação contra o devedor, para liberar-se da fiança, em quatro casos: 1) - quando o fiador já tivesse sido condenado a pagar; 2) - quando o devedor começasse a desfazer-se dos seus bens; 3) - quando vencido o prazo em que o devedor se obrigou a desonerar o fiador; 4) - quando o devedor protelasse demasiada e indèbitamente o cumprimento da obrigação (76).

No primeiro caso, indispensável era que o fiador já tivesse sido condenado - si neque condemnatus est, (77) - não sendo bastante que o credor estivesse dêle reclamado o pagamento (78).

(75) C., 2, 41, 5: — "Melius est intacta iura servari, quam post causam vulneratam, remedium quaerere".

(76) Dernburg, o. c., $\S 80$; Рюthiter, o. c., $1.0^{\circ}$ vol., n. 442; Troplong, o. c., n. 390 e ss.; Windscheid, o. c., 2.0 vol. $\S 480-$ Dos três primeiros casos tratam os imperadores Deocleciano e Maximino, C., 4, 35, 10: — "Si pro ea contra quam supplicas fideiussor, seu mandator-intercessisti, et neque condemnatus es, neque bona sua eam dilapidare postea coepissie comprobare possis, ut tibi iustum metuendi causam praebeat; neque ab initio ita te obligationem suscepisse, ut eam possis et ante solutionem convenire, nulla iuris ratione, antequam satis creditori pro ea feceris, eam ad solutionem urgeri certum est." - A êsses e ao quarto caso refere-se Marcelo, D., 17, 1. 38: — “ . est enim earum specierum iudicialis quaestio, per quam res expediatur, non absimilis illa, quae frequentissime agitari solet, fideiussior an et prius quam solvat agere possit, ut liberetur, nec tamem semper exspectandum est, ut solvat aut iudicio accepto condemnetur, si diu in solutione reus cessabit aut certe bona sua dissipabit, praesertim si domi pecunidm fideiussor non habebit, qua numerata creditori mandati actione reum conveniat".

(77) C., 4, 35, 10; D., 17, 1, 38.

(78) Pothier, o. c., $1.0^{\circ}$ vol., n. 442; Troplong, o. c., n. 393. 
No segundo caso, o devedor dilapidara seus bens, isto é, ficara falido ou insolvável - cum certa bona sua dissipavit (79). Todavia abrandava-se, na prática, o rigor da lei, concedendo-se ação ao fiador se o devedor começava a dissipar seus bens - neque postea bona sua dilapidari comprobare possis (80).

O terceiro caso se verificava quando o devedor convencionara, por ocasião da constituição da fiança - neque $a b$ initio - que desoneraria o fiador da obrigaçāo em certo lapso de tempo e o prazo se vencera (81).

O quarto caso ocorria, embora não houvesse prazo de vencimento da obrigação principal, quando o devedor não se movia por muito tempo e indevidamente para solvê-la - si diu in solutione reus cessabit (82).

b) $\mathrm{Na}$ espécie, o direito romano foi seguido, com ligeiras modificações e algum acrescentamento, pelo antigo direito francês (83) e êste reproduzido pelo Cód. Civil francês (84), nos seguintes têrmos: - "O fiador, mesmo antes de haver pago, pode agir contra o devedor, para ser por êle indenizado: $1^{\circ}$ ) - quando acionado para o seu pagamento; $2^{\circ}$ ) - quando o devedor seja falido ou se encontre em estado de insolvência; $3^{\circ}$ ) - quando o devedor se obrigou liberá-lo da garantia em certo tempo; $4^{\circ}$ ) - quando a dívida haja se tornado exigível pelo vencimento do têrmo convencionado; $5^{\circ}$ ) - após dez anos, quando a obrigação principal não tenha um têrmo de vencimento fixo, a menos que a obrigação principal, como acontece com a tutela,

(79) D., 17, 1, 38.

(80) C., 4, 35, 10.

(81) C., 4, 35, 10.

(82) D., 17, 1, 38.

(83) Pothier, o. c., 1.o vol., ns. 442-443; Troplong, o. c., n. 390 e ss.; Baudry-Lacantinerie et WaHL, o. c., 21.0 vol., ns. 1094-1098.

(84) Cód. Civil francês, art. 2.032. Troplong, o. e loc. cits.; Baudry-Lacantinerie et Wahl, o. e loc. cits.; Laureant, o. c., 28. vol., n. 252 e se.; Planiol, o. 'c., n. 2.361. 
seja de tal natureza que não possa extinguir-se antes de um prazo determinado".

Disposição semelhante foi acolhida pela legislação dos povos contemporâneos. (85).

c) Era a legislação pátria anterior, inclusive a das Ordenações Filipinas, omissa a respeito. Todavia, acompanhando o direito romano com as modificaçôes trazidas pelo Código Napoleônico, a doutrina brasileira (86), a par da portuguêsa, (87) consagrava o princípio que autorizava o fiador a acionar o devedor, ainda antes de pagar dívida, para que o liberasse da obrigaçăo, nos seguintes casos: $1^{\circ}$ ) - quando vencido o prazo para o pagamento do devedor; $2^{\circ}$ ) - quando o fiador tivesse sido condenado ao pagamento ou fosse acionado para pagar; $3^{\circ}$ ) - quando vencido o prazo que o devedor convencionara com o fiador para desonerá-lo da obrigação; $4^{\circ}$ ) — quando o devedor dilapidasse os bens; $\left.5^{\circ}\right)$ - quando, tratando-se de obrigação principal sem tempo determinado, se passassem dez anos e o devedor não procurasse pagá-la.

d) O Código Civil, porém, reduziu as hipóteses permissivas dêsse benefício do fiador, dispondo no artigo 1.499: - "O fiador, ainda antes de haver pago, pode exigir que o devedor satisfaça a obrigacão, ou o exonere da fiança, desde que a dívida se torne exigivel, ou tenha decorrido o prazo, dentro no qual o devedor se obrigou a desonerá-lo".

Em face dêsse texto, ao fiador, ainda antes de haver pago a dívida, é concedida ação contra o devedor, para que satisfaça a obrigação ou o exonere da fiança, tão sòmente em dois casos: $1^{\circ}$ ) — se a dívida se tornou exigivel;

(85) Cód. Civil italiano, de 1865, art. 1.919; italiano, art. 1.953; português, art. 844; alemão, § 775; espanhol, art. 1.843 .

(86) Carvalho de Mendonga (M. I.), o. c., 2.0 vol., n. 388.

(87) Coelho Rocha, o. c., $20^{\circ}$ vol., $\S 885$; Corrêa Teles, o. c., 1.0 vol., n. 441. 
$\left.2^{\circ}\right)$ - se decorrido o prazo dentro no qual o devedor se obrigou a desonerá-lo (88).

Não é de falar-se na extensão do benefício a outras hipóteses, pois que, como exceção que é aos princípios que regem a fiança e as obrigações do fiador, não se compreende possa aplicar-se por analogia a outros casos (89).

$\mathrm{O}$ direito do fiador agir, antes de pagar a dívida, a fim de que o devedor o libere - ut liberetur, dizia Marcelo (90) - e a que não se andaria errado chamando de beneficium liberationis, poderá ser exercido mesmo quando a fiança haja sido prestada sem consentimento do devedor? A essa questão há quem responda que sim (91). A opinião oposta, (92) porém, parece ser a acertada. Sem o consentimento do devedor a fiança lhe é um ato estranho e seria injusto ficasse o fiador armado do poder de fazer forçar um pagamento que, não fôsse o fiador, não seria tão logo exigido pelo credor. Certo é que nenhum interêsse tem o problemá no segundo caso do artigo 1.499 - quando tenha decorrido o prazo dentro no qual o devedor se obrigou a desonerar o fiador - em que é pressuposta uma convenção entre êles e, portanto, está claro o consentimento do devedor na prestação da fiança. Diz respeito apenas à primeira hipótese, isto é, porque a dívida se tornou exigível (93). Neste

(88) Clóvis Bevilaqua, o. c., 5.0 vol., p. 265; João Luiz Alves, Código Civil Anotado, ed. 1926, pág. 1.078; Carvalho Santos, o. c., $19 .^{\circ}$ vol., pág. 478 e ss.

(89) Cf. Laureint, o. c., 28.0 vol., n. 258; Troplong, o. c., n. 410.

(90) D., 17, 1, 38.

(91) Troplong, o. c., n. 412.

(92) Clóvis Bevilaqua, o. e loc. cits.; João luiz Alves. o. e loc. cits.

(93) "Na hipótese em que o credor deixa de cobrar a dívida já exigível, se a fiança foi dada, sem ciência e consentimento do devedor, é para êle, como já notamos, res inter alios, que nenhuma obrigação jurídica lhe pode acarretar, senão a de cumprir a obrigação, quando o credor lha exige, quando o fiador usar do benefício de ordem e quando, depois de pagá-la, ficar o fiador subrogado no direito do credor" (JoÃo LUIZ ALVES, o. e loc. cits.). 
caso, se a fiança foi instituída sem consentimento do devedor, o fiador terá que sujeitar-se a aguardar a iniciativa do credor, reclamando o pagamento, e então utilizar-se do benefício de ordem (94), ou pagar e subrogar-se nos direitos do credor (95).

8. Servirão as noções expostas para melhor debate e entendimento das ações cominatórias concedidas ao fiador - uma, para exigir que o afiançado satisfaça a obrigação ou o exonere da fiança (Código de Processo, art. 302, n. I) ; outra, para exigir que o credor acione o devedor (Cód. de Processo, art. 302, II) - cujo estudo será feito nos parágrafos seguintes.

(94) Vide n. 5.

(95) Vide n. 6. 